\title{
VIRUS-LIKE PARTICLES IN HUMAN LEUKEMIC CELLS - II
}

Sir:

Following our previous communications to your readers (Torrioli et al. 1972 and 1973), we should now like to report on further results in our studies on human leukemia.

As usual, human leukemic blood was inoculated into fertile, virus- and mycoplasm-free, cofalnegative chicken eggs. After several egg-to-egg transmissions, embryo membranes were processed and examined with electron microscopy techniques. The same blood $(0.2 \mathrm{ml})$ was added to human normal blood cultures in 199 medium containing $0.36 \%$ phytohemoagglutinine after one day of incubation. The EM preparation was performed after 8 days, following short centrifugation at $1000 \mathrm{~g}$. Normal human blood cultures treated with the same procedures were used as controls. Further details on our standard technique and on EM analysis may be found in our cited papers.

Virus-like particles, similar to those previously described, were observed in the cytoplasm of both the perivascular connective tissue cells of the infected egg membranes and the cultured blood cells contaminated with leukemic blood. Remarkably enough, the particles observed in the infected egg membrane cells and those observed in the infected blood cells were substantially identical.

These findings are consistent with our hypothesis the VLPs can be transmitted from leukemic blood into suitably cultured cells, and therefore strongly support the hypothesis of a viral etiology of human leukemia.

The effective technical cooperation given by Mr. Robert P. Wright is to be thankfully acknowledged.

Rec. 3.x.1974

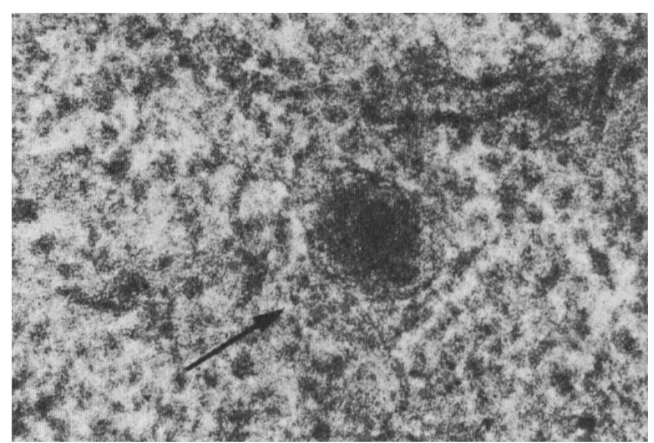

VLP in the cytoplasm of a cultured blood cell infected with human leukemia (case no. 41). Another overimposed VLP is barely visible. $(112,500 \times)$.

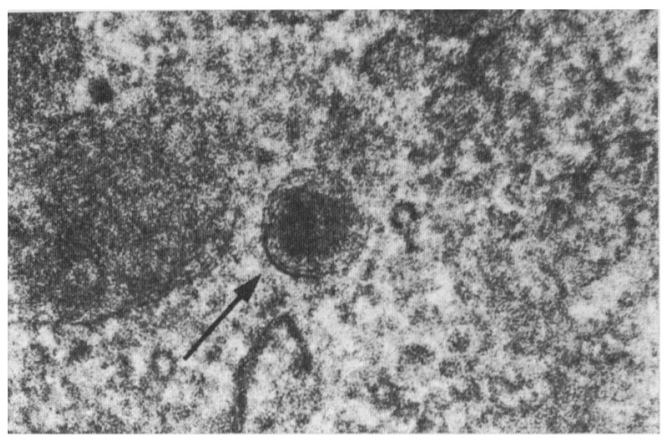

VLP in the cytoplasm of a cultured chicken embryo cell infected with human leukemia (case no. 55). $(112,500 \times)$.

References:

Torrioli M., Torrioli-Riggio G., Braconi-Romei L., Conforti A., Russo M. 1972. Virus-like particles in human leukemic cells. Acta Genet. Med. Gemellol. (Roma), 21: 271.

Torrioli M., Torrioli-Riggio G., Braconi-Romei L., Torrioli E., Merlini D., Russo M., Conforti A. 1973. Viral etiology of leukemias. Electronmicroscope observation of virus-like particles. Acta Genet. Med. Gemellol. (Roma), 22: 99-107.

G. Torrioli-Riggio

The Gregor Mendel Institute for Medical Genetics and Twin Studies

Rome, Italy

and

A. Conforti, M. Russo

University Department of General Pathology Rome, Italy 